\title{
KOPIEC KOŚCIUSZKI W KRAKOWIE - POMNIK HISTORII. KONSERWACJA, ZARZĄDZANIE, PROMOCJA
}

\section{ROKOSZ Mieczysław $^{1}$}

\footnotetext{
${ }^{1}$ Prof. nadzw. dr hab. Mieczysław Rokosz, prezes Komitetu Kopca Kościuszki w Krakowie https://orcid.org/0000-0003-1248-1051
}

ABSTRAKT: Kopiec Kościuszki zbudowany w l.1820-1823 przez Naród Polski jako symboliczna mogiła za pomnik dla Tadeusza Kościuszki jest drugą, obok Wawelu, znaczącą subdominantą w krajobrazie kulturowym Krakowa. W poł. XIX w. wokół Kopca zbudowano fort cytadelowy o cechach neostylowych, uznany za arcydzieło architecturae militaris. W r. 1936 Kopiec został wpisany do rejestru zabytków, a w 2017 r. rozporządzeniem Prezydenta RP wraz z otoczeniem został uznany za pomnik historii. Jako budowla ziemna Kopiec podlega nieustannym procesom destrukcji, powodowanym siłami natury. Stałą pieczę konserwatorską nad nim sprawuje Komitet Kopca Kościuszki ustanowiony w 1820 r. Komitet troszczy się też o otoczenie pomnika restaurując podległe mu części fortu. Sukcesem konserwatorskoadaptacyjnym jest przekształcenie kurtyny południowej (czyli wału ziemnego umocnionego murem, z pochylnią do wytaczania dział) w wielokubaturowe, dwukondygnacyjne centrum konferencyjnowystawowe. Komitet wpływa też na prześwietlenie samosiewnego lasu wokół Kopca i na przedpolu fortu, w celu odsłonięcia tego zabytkowego zespołu. W pozostałych, podległych Komitetowi częściach fortu, organizowane są wystawy kościuszkowskie, a docelowo ma tu powstać muzeum Kościuszki. Pośród przedsięwzięć mających promować Kopiec Kościuszki z otoczeniem, jako obiekt o wartościach historycznych, architektonicznych i krajobrazowych - materialnych i niematerialnych są liczne publikacje polskie i obcojęzyczne, wykłady głoszone w Polsce, ale też w Stanach Zjednoczonych, Francji, Szwajcarii i Australii. Najlepszym świadectwem ugruntowanego miejsca Mogiły Kościuszki w polskiej przestrzeni i w geografii globu oraz w świadomości Polaków i wielu cudzoziemców jest ogromna i systematycznie wzrastająca frekwencja.

SŁOWA KLUCZE: Kopiec Kościuszki, symboliczna mogiła, pomnik, konserwacja, zarządzanie, promocja

\section{Treść ideowa zabytku. Odrobina historii}

Kopiec Kościuszki został wzniesiony w latach 1820 - 1823 na podobieństwo przedhistorycznych, legendarnych, podkrakowskich mogił Kraka i Wandy. Został wzniesiony wysiłkiem rąk i ofiarą pieniężną narodu polskiego, jako symboliczna „mogiła za pomnik” dla zmarłego w Solurze 15 X 1817 r. bohatera narodowego Stanów Zjednoczonych, obywatela honorowego Republiki 
Francuskiej, Naczelnika Insurekcji 1794 r. gen. Tadeusza Kościuszki. Został wzniesiony „Z ojczystej ziemi i głazu krajowego” na „znak wiecznotrwały” niepodległości i pamięci o bohaterze. Inauguracja budowy Kopca na górze św. Bronisławy nad starą stolicą Polski przebiegła $\mathrm{w}$ aurze święta narodowego. Równocześnie w synagodze na Kazimierzu gmina żydowska uroczystym zgromadzeniem uczciła pamięć Kościuszki. Zaraz też powiadomiono jego przyjaciół we Francji, Anglii i Stanach Zjednoczonych o rozpoczętej budowie pomnika. Sprawa więc - można rzec - nabrała międzynarodowego rozgłosu.

U podstawy Kopca złożono ziemie z pola racławickiej bitwy i mogiły poległych. W trakcie budowy zdeponowano w nim ziemie z pól bitewnych pod Dubienką, Szczekocinami i Maciejowicami. Zaś 4 lipca 1926 r. w głowicy Kopca „złożono ziemię z pobojowisk w Ameryce na dowód i wspomnienie udziału Tadeusza Kościuszki w wojnie o niepodległość Stanów Zjednoczonych w 150 rocznice jej ogłoszenia”. Można więc rzec, że na zasadzie pars pro toto, Kopiec został zbudowany z ziemi zroszonej krwią i zmieszanej z prochami bohaterów. Był wznoszony pod nadzorem Komitetu Zarządzającego Budową Pomnika, któremu przewodniczył generał wojsk polskich byłego Księstwa Warszawskiego Franciszek Paszkowski. Budowę nadzorowali Feliks Radwański, Feliks Radwański junior, Szczepan Humbert i Franciszek Wincenty Sapalski - najlepsi specjaliści w zakresie budownictwa, jakimi dysponowało Wolne Miasto Kraków i Uniwersytet Jagielloński. Po wzniesieniu mogiły Komitet się nie rozwiązał, lecz stanął na straży tego pomnika i narodowej pamiątki jako Komitet Konserwacji Mogiły Pomnika Kościuszki. W latach trzydziestych XIX w. z funduszy członków Komitetu uregulowano starą gruntową drogę ze Zwierzyńca na Kopiec i obsadzono ją drzewami. Jest to dziś pełna pomnikowych drzew Aleja Waszyngtona. W roku 1860 prezes Komitetu Piotr Moszyński zwieńczył Kopiec trzytonowym głazem tatrzańskiego granitu. Pomnikowy ten głaz z najtreściwszą inskrypcją dedykacyjną: KOŚCIUSZCE - był planowany przez budowniczych od początku, czekano tylko na stabilizację bryły tej ziemnej budowli. Komitet zwany od 1937 r. Komitetem Kopca Kościuszki istnieje do dziś, nieprzerwanie sprawując opiekę nad Kopcem ${ }^{1}$. Kopiec natychmiast po wzniesieniu stał się górą pielgrzymkową Polaków i miejscem narodowych manifestacji. Dla pokoleń żyjących w niewoli, pod zaborami, był znakiem wiary w niepodległość i zmartwychwstanie Polski, był

\footnotetext{
${ }^{1}$ Dzieje budowyi dalszą historię Kopca i opiekującego się nim Komitetu zob. m. in. w: Pamiętnik budowy Pomnika Tadeusza Kościuszki przez Komitet zarządzający tąż budowa wydany, Kraków 1825 [1826], tu dokumenty, plany i Lista imienna osób składających ofiary na Pomnik Tadeusza Kościuszki; Dodatek do Pamiętnika budowy Pomnika Tadeusza Kościuszki wydanego w 1826 roku, obejmujący sprawozdanie Komitetu Pomnikiem tym zarządzającego za czas do 1 lipca 1852 r. Kraków 1852; Dodatek drugi do Pamiętnika Pomnika Kościuszki obejmujący czas od 1 lipca 1851 do końca 1876 roku. Kraków 1878. Zob. też Rożek M., Kopiec Kościuszki w Krakowie. Wydawnictwo Literackie Kraków 1981; Gordziałkowski J., Dzieje Komitetu Kopca Kościuszki (1820 - 1994) [w:] Kościuszce w hołdzie, red. M. Rokosz, Kraków 1994, s. 85 - 184; Rokosz M., Najkrótsza historia budowy i napraw Kopca Kościuszki „z ojczystej ziemi i z głazu krajowego” [w:] Kopiec Kościuszki i jego podłoże geologiczne. Atlas Przewodnik. red. A. Wójcik, wyd. Urząd Miasta Krakowa, Wydział Kształtowania Środowiska, Kraków 2016, s. 6 - 22; Danowska E., Jak powstawał Kopiec Kościuszki w Krakowie - jego dzieje w czasach Rzeczypospolitej Krakowskiej [w:] „Krakowski Rocznik Archiwalny” XXIII, Kraków 2017, s. 45 - 63; Rokosz M., Kopiec Tadeusza Kościuszki w Krakowie - znak wiecznotrwały [w:] Rozważny i romantyczny. W 200. Rocznicé śmierci Tadeusza Kościuszki. Muzeum Historyczne Miasta Krakowa. Kraków 2017, s.193 - 211.
} 
miejscem narodowej pamięci, na które przybywał weteran walk, nauczyciel z dziatwą szkolną, rodzice z dziećmi, gimnazjaliści i akademicy, panowie i chłopi - wszyscy ${ }^{2}$.

W 1.1850 - 56 austriackie władze wojskowe, realizując plan budowy Twierdzy Kraków, wzniosły wokół Kopca Kościuszki potężny, mający bronić dostępu do rdzenia twierdzy od zachodu, fort nr 2 „Kościuszko”. Kopiec został otoczony murem oporowym, w ramach którego zbudowano neogotycką kaplicę bł. Bronisławy, i pozostał pod wyłącznym zarządem Komitetu ${ }^{3}$. Został wpisany do ksiąg wieczystych jako Narodowa Fundacja Mogiły [Pomnika] Tadeusza Kościuszki Znaczy to, że Kopiec ten jako rzecz ufundowana przez naród polski pozostaje własnością narodu pod zarządem reprezentującego go Komitetu. Tak więc jedna morga wiedeńska ziemi z wznoszącym się na niej Kopcem, za którą Komitet nie uiszczał podatku gruntowego - była traktowana jako niepodległy skrawek ziem Rzeczypospolitej. Na tym też zapisie prawnym opierała się jego symboliczna wymowa jako znaku niepodległości. Dostęp do Mogiły, mimo otoczenia jej fortem, był wolny przez wszystkie dni od świtu do zmierzchu, z wyjątkiem stanu wojny. Wspomniana kaplica bł. Bronisławy w stylu neogotyckim jest niepodzielnym dziełem Feliksa Księżarskiego, który też ponad wszelką wątpliwość według współczesnych źródeł, mając poparcie i uznanie ck podpułkownika Juliusza Wurmba, pracował w Dyrekcji Fortyfikacji5.

Fort „Kościuszko” ze związanymi z nim bezpośrednio fortyfikacjami, był największym dziełem obronnym Twierdzy. Został uznany za wybitne dzieło architecturae militaris ${ }^{6}$. Na obecnej alei Waszyngtona, która dostosowana do potrzeb transportu wojskowego w górnym swym odcinku zmieniła nieco swój przebieg, zbudowano most nad wytyczoną w poprzek drogą. Dziś ten tzw.

\footnotetext{
$2 \quad$ Gordziałkowski J., Kopiec Kościuszki - miejsce pielgrzymek Polaków [w:] 180 lat Kopca Kościuszki [w:] Materiały z sesji naukowej odbytej 15 kwietnia 2000 roku. Towarzystwo Miłośników Historii i Zabytków Krakowa. Kraków, s.15 - 103 ; Rokosz M., Kopiec Kościuszki w Krakowie: czym jest i co znaczy / Krakow's Kościuszko Mound what is and its significance? [w:] Tadeusz Kościuszko - historia, współczesność, przyszłość. Relacje i zależności. Red. nauk. M. J. Żychowska. Politechnika Krakowska im. Tadeusza Kościuszki. Kraków 2017, s. 119 - 125. Rokosz M., Le tertre do Kościuszko a Cracovie: Quest - ce que c'est et quelle est sa signification? [w:] „Annales Academie Polonaise des Sciences. Cntre Scientificque a' Paris” vol 19, 2017, s. 158 - 176.

Gwarantował to punkt 3 Aktu odstąpienia gruntów około pomnika Kościuszki na budowę fortyfikacji zawarty 21 IV 1852 r. w Krakowie miedzy przedstawicielami „Komitetu zarządzającego pomnikiem [Kopcem Kościuszki] a przedstawicielami austriackiego Ministerstwa Wojny - zob. Dodatek do Pamiętnika budowy Pomnika Tadeusza Kościuszki.....op. cit. S. 65 -67.

$4 \quad$ Archiwum Narodowe w Krakowie („dalej: AN Kr) zespół: Komitet Pomnika Kościuszki, sygn.. 7: Hipoteka. Zapis ten został odnowiony w 1906, zob. tamże.

Zob. „Czas” 1860 nr 202, s. 3; Moraczewski M., Nekrolog Feliksa Księżarskiego, „Czasopismo Techniczne” Lwów 1884 R.2, nr 4, s. 51; zob. też Biblioteka Jagiellońska rkps 7927 IV: Stacherski A., O budowniczych krakowskich w czasach naszych i stawianych przez nich budowlach, 1961 , karta $196 \mathrm{nn}$ - por. Białkiewicz Z. J., Feliks Księżarski - krakowski architekt romantycznego historyzmu i dojrzałego eklektyzmu „Rocznik Krakowski” R. LV, Kraków 1989, s. 171, 175; zob. też Bogdanowski J., Fortyfikacje austriackie na ziemiach polskich w latach 1850 - 1914 „ „Studia i materiały do Historii Wojskowości” t. 12, 1966, s. 76.

Zob. Fort 2 „Kościuszko” [wstępy: M. Rokosz, J. Janczykowski] „Atlas Twierdzy Kraków” Seria I, Tom 3, Towarzystwo Miłośników Historii i Zabytków Krakowa - Komitet Kopca Kościuszki, Kraków 1994; Janczykowski J. , Historia i rewaloryzacja Fortu 2 „Kościuszko” [w:] 180 lat Kopca Kościuszki. Materiały z sesji naukowej odbytej 15 kwietnia 2000 roku. Towarzystwo Miłośników Historii i Zabytków Krakowa. Kraków 2000, s. $147-166$.
} 
„Most diabelski” jako wczesny przykład bezkolizyjnego skrzyżowania, jest cennym zabytkiem drogownictwa.

Po 1918 r. w odrodzonej Rzeczypospolitej, na mocy zawartego 1 lipca 1924 r. układu z przedstawicielem Rządu, Komitet pozostał przy swych prawach i obowiązkach i nadal sprawował opiekę nad symboliczną Mogiłą Naczelnika, w czym walnie dopomagały mu władze wojskowe ${ }^{7}$. Zaraz też po ustanowieniu urzędu wojewódzkiego konserwatora zabytków w Krakowie, Kopiec Kościuszki i jego otoczenie znalazło się w polu widzenia konserwatora Tadeusza Szydłowskiego. „Konserwator współdziałał z Komitetem Konserwacji Mogiły Kościuszki”. Zadbano o ,uporządkowanie i zabezpieczenie stoków mogiły”. Następnie zaś poza obrębem fortu „wyznaczono ścisłe granice rejonu” wyłączonego od zabudowy, „by widok na mogiłę nie uległ zeszpeceniu, a jej powaga jako pomnika narodowego nie doznawała ujmy". 16 lipca 1929 r. Kopiec odwiedził prezydent Rzeczypospolitej Ignacy Mościcki9. W roku zaś 1936 decyzją konserwatora okręgu krakowskiego inż. Bohdana Tretera z dnia 20 października Kopiec Kościuszki został wpisany do Rejestru zabytków nieruchomych (dział A) pod nr 954 ${ }^{10}$.

W czasie II wojny generalny gubernator Frank planował niwelację Kopca Kościuszki ${ }^{11}$. Po wojnie władze PRL, mimo szafowania hasłami kościuszkowskiej demokracji, nie wspomagały Komitetu w trosce o Kopiec, który ulegał destrukcji ${ }^{12}$.

W czerwcu 2015 r. Komitet w przeświadczeniu o wyjątkowych wartościach Kopca Kościuszki i jego otoczenia, przy poparciu prezydenta Krakowa oraz poparciu i pomocy Miejskiego Konserwatora i Konserwatora Wojewódzkiego podjął starania o uznanie Kopca Kościuszki za

\footnotetext{
ANKr zespół: KPK sygn. 6: Układ w przedmiocie uregulowania stosunków prawnych Pomnika (Mogiły) Tadeusza Kościuszki, zawarty dnia dzisiejszego między dowództwem Okr. Korp. Krakowskiego, działającym w imieniu Rządu względnie Skarbu Państwa Polskiego na zasadzie uprawnienia Ministerstwa spraw wojskowych $z$ dnia 1 lutego 1923. L. 20699 V.W.III. a Komitetem Pomnika Tadeusza Kościuszki na zasadzie uchwały tegoż Komitetu $z$ dnia 20 lipca 1923 r. Układ ten w imieniu władz wojskowych podpisał płk. Jan Skoryna, szef inżynierii i saperów Dowódca Okregu Korpusu V a w imieniu Komitetu - prezes dr Franciszek Paszkowski i sekretarz dr Klemens Bakowski.

$8 \quad$ Szydłowski T., Opieka nad zabytkami miasta Krakowa. Z działalności Urzędu konserwatorskiego [w:] „Rocznik Krakowski” 20, 1926, s. 192; tenże, Kronika konserwatorska z lat 1925 do 1928 [w:] „Rocznik Krakowski" 22, 1929, s. 143.

$9 \quad$ Z tej okazji założono nowa Księgę pamiątkową dla zwiedzających Kopiec, w której na s. 5 złożył swój podpis prezydent i stanowiący jego świtę przedstawiciele władz wojskowych i cywilnych Krakowa w tym również prezydent miasta i prezes Komitetu Dr Karol Rolle - zob. ANKr. Zespół KPK sygn. 17 - wizyta prezydenta i KPK 44 Księga pamiątkowa. Zob. też zdjęcia Władysława Pikiela - fotografa-ilustratora Wojskowego Instytutu Naukowo-Wydawniczego w Warszawie, w Zbiorach Komitetu Kopca Kościuszki.

10 Cytowany wyżej Rejestr... przechowywany jest w Urzędzie Wojewódzkiego Konserwatora Zabytków w Krakowie. Odpis orzeczenia konserwatora Tretera w tej sprawie przesłany na ręce prezesa Komitetu Karola Rollego w registraturze Komitetu, teczka : Status prawny Kopca i Komitetu. Orzeczenia i ekspertyzy.

11 Wroński T., Kronika okupowanego Krakowa. Kraków 1974, s. $150 \mathrm{nr} 874$ i por. Rożek M., Kopiec Kościuszki... op. cit., s. 158 -160.

12 Od marca 1949 opiekę nad Kopcem sprawował prof. Karol Estreicher, członek Komitetu od 1931 i członek Wydziału (Zarządu) Towarzystwa Miłośników Historii i Zabytków Krakowa; zob. tegoż Dziennik wypadków, t. II: 1946 - 1960. Kraków 2002, s. 150, 288 -289, 711, 774.
} 
pomnik historii. Jak wyżej podkreśliliśmy, Kopiec ten wzniesiony jako pomnik, podlega ściśle definicji, która według Samuela Bogumiła Lindego mówiła, że pomnik „to monument dla pamięci lub na pamiątkę wystawiony". Rozporządzeniem Prezydenta RP Andrzeja Dudy z 22 listopada 2017 r. Kopiec Kościuszki wraz otoczeniem ,ze względu na wartości historyczne, architektonicznei krajobrazowe - materialne iniematerialne [...] pomnika-mogiły wzniesionego przez Naród Polski dla uczczenia wielkiego wodza i bohatera narodowego, będącego symbolem patriotyzmu i dążeń niepodległościowych, tworzący kompozycję krajobrazową wpisaną w panoramę historycznego Krakowa" został uznany za pomnik historii ${ }^{13}$.

\section{Konserwacja}

Kopiec został wzniesiony na wysokości 300 m. n. p. m. więc 100 m. nad poziom krakowskiego Rynku, na wysokość $35 \mathrm{~m}$. Jest stożkiem ściętym z ziemi lessowej na podstawie okrągłej o średnicy $80 \mathrm{~m}$, średnica platformy widokowej na szczycie Kopca wynosi 8 m. Objętość Kopca to 70 tys. $\mathrm{m}^{3}$ ziemi. Na jego platformę widokową wiodą dwie spiralne przecinające się ścieżki, czyli tzw. „,podwójna ślimacznica”. Był wzniesiony w romantycznym porywie serc jako budowla ziemna o stromych skarpach, których kąt przekracza kąt zsypu gruntu lessowego stanowiącego budulec pomnika. Kopiec był „sypany” bez zastosowania jakichkolwiek konstrukcji np. kamienno-bierwionowych, czy warstw faszyny. Jedynym elementem konstrukcyjnym był ok. 30 metrowy pień jodły „,z lasów śląskich” spod Jaworzna, mający wyznaczać środek i pion budowli. Sypane warstwy ziemi były utwardzane na miarę ówczesnych możliwości technicznych, a skarpy darniowano. Roboty trwały przez trzy sezony budowlane (1821 -1822 - 1823 r.). Kopiec zaraz po usypaniu został uznany za „, najpiękniejszą i największą [mogiłę], która kiedykolwiek i gdziekolwiek na świecie usypaną była" ${ }^{14}$, a ze swym systemem komunikacyjnym był godną podziwu konstrukcją geotechniczną na miarę swego czasu. A przede wszystkim był miejscem narodowej pamięci.

Właściwości, zastosowanego jako budulec, gruntu lessowego polegające na łatwej higroskopii, brak jakiegokolwiek rusztu wewnętrznego, słabe utwardzenie kolejnych warstw nasypu i stromość skarp - wszystko to czyniło i czyni Kopiec szczególnie wrażliwym na destrukcyjne działanie sił natury. Topniejące śniegi i ulewne deszcze świętojańskie są powodem erozji i naturalnych szkód w postaci pełzania ziemi, pęknięć bryły i osuwisk. Zjawiska te występowały już w czasie budowy i cały czas później. Komitet nie dopuszczał do katastrofy. Już w latach trzydziestych XIX w. obsadzono podstawę Kopca - jak świadczą liczne przekazy ikonograficzne - szybko rosnącymi topolami. W połowie XIX w. austriackie władze wojskowe oddzieliły Kopiec od fortu, otaczając jego podstawę ceglanym murem oporowym. Kolejną poważniejszą inwestycją konserwatorską na Kopcu było zainstalowanie w roku 1924 kamiennych „,rynienek” odpływowych wód opadowych, wybrukowanie ścieżek wapieniem jurajskim (taki sam bruk założono wtedy na obu podejściach na Wawel), pawimentacja platformy widokowej i otoczenie jej balustradą z czerwonego piaskowca świętokrzyskiego.

\footnotetext{
13 Dziennik Ustaw Rzeczypospolitej Polskiej. Warszawa, dn. 7 grudnia 2017 r. Poz. 2267.

14 Pamiętnik budowy... Op. Cit., s. 68.
} 
Po 1945 r. kondycja Mogiły-Pomnika pogarszała się w sposób oczywisty. Również bezpośrednie otoczenie Kopca ulegało dewastacji skutkiem podjętych w 1946 r. przez gen. Michała Rolę Żymierskiego, decyzji o rozbiórce fortu „Kościuszko” jako symbolu austriackiej niewoli15. Został wtedy rozebrany, częściowo zrujnowany już pod koniec wojny, zachodni, bastionowy front fortu. Dalsza rozbiórka fortu została wstrzymana w 1956 r. wskutek protestu krakowskiego środowiska naukowego z prof. Januszem Bogdanowskim na czele ${ }^{16}$. Ruiny zaczęły porastać samosiewnym lasem. Skutkiem starań profesora Karola Estreichera, prezesa Komitetu, w latach 1979 -1980 władze wojskowe opracowały plan naprawy Kopca. Zdecydowano się na mechaniczne wzmocnienie pomnika przez mikropale betonowe o średnicy $10 \mathrm{~cm}$, długie na 7 do $10 \mathrm{~m}$. wwiercane w jego bryłę na wysokości ścieżek ${ }^{17}$. W latach 1989 -1990 trzeba było przeprowadzić kolejny remont. Tym razem starano się wzmocnić Kopiec metodą kotew betonowych. Autorami projektu byli profesorowie Instytutu Geotechniki Politechniki Krakowskiej prof. Stanisław Datka i prof. Julian Pałka ${ }^{18}$. Remonty te jednak nie zapobiegły kolejnym destrukcjom powodowanym siłami natury.

Ulewne deszcze w czerwcu i lipcu 1997 r. spowodowały na Kopcu zniszczenia, które oceniono jako największą w jego dziejach katastrofę budowlaną ${ }^{19}$. Ulewy roku następnego pogłębiły ten stan. Wystąpiły osuwiska mas ziemi, Kopiec zaczął pękać przez pół do głębokości kilku metrów, platforma widokowa przechylała się w kierunku południowym co groziło osunięciem się pomnikowego głazu ze szczytu wprost na kaplicę. Po usilnych staraniach Komitetu uzyskano fundusze ze Skarbu Państwa i Narodowego Funduszu Ochrony Środowiska i firma HydrotrestSkanska od 5 grudnia 1999 do końca października 2002 roku przeprowadziła remont zabezpieczający Kopiec ${ }^{20}$. Został odrestaurowany jako „wiecznotrwały znak niepodległości Polski i solidarności narodów w imię dobra ludzkości" - jak czytamy na tablicy pamiątkowej ufundowanej na Kopcu z tej okazji. W wigilię święta narodowego 11 listopada 2002 r. Kopiec Kościuszki został uroczyście na nowo otwarty.

Zasadnicze znaczenie konserwatorskie ma codzienna pielęgnacja trawnika na skarpach Kopca, jego dosiewanie i koszenie. Prowadzony jest też systematyczny monitoring geodezyjny ruchów pionowych i poziomych bryły Kopca.

15 Żymierski osobiście 10 października 1946 r. w ramach obchodów piątej rocznicy bitwy pod Lenino, symbolicznie rozpoczął dzieło dewastacji odkuwając pierwszą cegłę.

16 Bogdanowski J., Fortyfikacja austriacka na ziemiach polskich w latach 1850 - 1914. „Studia do Historii Wojskowości” t. XII, cz. 1, Warszawa 1966, s. 71.

17 Rokosz M., Najkrótsza historia budowy i napraw Kopca.... Op. cit., s. 18.

18 Pałka J., Datka K., Musiał K., Opracowanie sposobu kotwienia Kopca Kościuszki wraz ze szczegółowymi wytycznymi realizacji zabezpieczenia. Instytut Geotechniki Politechniki Krakowskiej 1990.

19 Rokosz M., Katastrofa Kopca Kościuszki i w 1997 roku i pierwsze próby ratowania zabytku [w:] 180 lat Kopca Kościuszki... j. w., s. 167 - 175.

${ }_{20}$ Tylutki J., Założenia projektowe odbudowy Kopca Kościuszki w Krakowie [w:] 180 lat Kopca Kościuszki... s. 177 - 181; zob. też Sprawozdania z czynności Komitetu Kopca Kościuszki ..... „Rocznik Krakowski” t. LXVLXVI, 1999-2000, s. 183 - 185; „Rocznik Krakowski” t. LXVII, 2001, s. 157 - 159; „Rocznik Krakowski” t. LXVIII,2002, s. 235-237; , Rocznik Krakowski” t. LXIX, 2003, s. 237-239. 
Ostatnie ćwierćwiecze przyniosło zasadnicze zmiany nie tylko w opiece nad Kopcem, ale też nad jego bezpośrednim otoczeniem. Umożliwiły to m.in. dotacje Społecznego Komitetu Odnowy Zabytków Krakowa, jak też możliwość wykorzystywania Funduszy Europejskich.

Komitet od roku 1994 przejmując sukcesywnie od gminy Kraków najbardziej zrujnowane części fortu, a to kaponierę południową w 1994 r., bastion V wraz z dziedzińcem wewnętrznym w 1996 r., a wreszcie też kurtynę I-V w 1997 r. , przystępował do podnoszenia ich z ruiny, z przeznaczeniem na cele wystawowe, konferencyjne i muzealne. Prace konserwatorskie na wszystkich obiektach prowadziła Pracownia Konserwacji Zabytków „Arkona” według własnych projektów za pozyskane przez Komitet pieniądze z funduszy europejskich i z Narodowego Funduszu Rewaloryzacji Zabytków Krakowa dysponowanego przez Społeczny Komitet Odnowy Zabytków Krakowa. W wyniku prac konserwatorsko-adaptacyjnych mamy cztery obiekty o łącznej powierzchni użytkowej $2388,39 \mathrm{~m}^{2}$ o kubaturze $13159,8 \mathrm{~m}^{3}$. Z tego na trzy kondygnacje kaponiery przypada $210 \mathrm{~m}^{2},\left(630 \mathrm{~m}^{3}\right)$, na bastion $779 \mathrm{~m}^{2},\left(92796 \mathrm{~m}^{3}\right)$, na zadaszony dziedziniec $320 \mathrm{~m}^{2},\left(2560 \mathrm{~m}^{3}\right)$ i na kurtynę $1079 \mathrm{~m}^{2},\left(7200 \mathrm{~m}^{3}\right)$.W czasie remontów kurtyna i bastion przystosowane zostały do potrzeb osób niepełnosprawnych ruchowo.

Za największy sukces konserwatorsko-adaptacyjny wypada uznać rewitalizację kurtyny I-V i przekształcenie jej w obiekt o przeznaczeniu konferencyjno-wystawowym. Prace trwały od września 2011 do maja 2013 roku. Kurtyna - czyli wał ziemny umocniony ceglano-kamiennym murem, z pochylnią do wytaczania dział - z niszczejącą koroną swych murów (krenelażem) i porastająca samosiewnym lasem, została zamieniona $\mathrm{w}$ dwukondygnacyjną budowlę o łącznej powierzchni $1097 \mathrm{~m}^{2}$, przeznaczoną na Centrum konferencyjno-wystawowe im. Tadeusza Kościuszki. Osiągnięto to przez oczyszczenie budowli z ziemi, odrestaurowanie murów, zadaszenie poziome (na dachu taras) i podzielenie całej kubatury na dwie kondygnacje z klatką schodową i windą. Prace te wykonała Pracownia Konserwacji Zabytków „Arkona” według projektu mgr inż. arch. Grażyny Safrugi. Dzieło służące kiedyś artyleryjskiej obronie stało się - można rzec - świątynią Muz i miejscem spotkań. W roku 2014, w ramach ogłoszonego przez Generalnego Konserwatora Zabytków - Piotra Żuchowskiego, konkursu na zabytek zadbany, Komitet otrzymał wyróżnienie ,za starannie przeprowadzoną konserwację i adaptację zrujnowanej kurtyny I-V południowej Fortu nr 2 „Kościuszko”, jednego z najstarszych zachowanych dzieł obronnych Twierdzy Kraków, pozwalającą wydobyć walory zabytkowe obiektu i nadać mu nowe wartości użytkowe".

W ciągu ostatnich 25 lat Komitet kilkakrotnie zmieniał wystawy o tematyce kościuszkowskiej $\mathrm{w}$ kaponierze, bastionie, a ostatnio też w kurtynie. Obecnie w kaponierze jest wystawa: „Twierdza i miasto - Kraków”. W bastionie zaś - wystawa kościuszkowska. Wspomnijmy, że celem Komitetu od początku jego istnienia było prócz codziennej troski o Kopiec Kościuszki utworzenie muzeum Kościuszkowskiego i w tym celu Komitet gromadził zbiory ${ }^{21}$. Aktualnie trwa zaawansowany remont konserwatorsko-adaptacyjny obejmujący zadaszenie dziedzińca, bastionu i parteru kurtyny w celu urządzenia tu stałej wystawy muzealnej „Kościuszko bohater

${ }^{21}$ Niezabitowski M., Zbiory Komitetu Kopca Kościuszki i Muzeum Kościuszkowskie w Krakowie [w:] 180 lat Kopca Kościuszki... j. w. , s. 123 - 145. 
wciąż potrzebny”. Wystawę tę zamierzamy otworzyć jesienią 2020 roku świętując 200-lecie Kopca i Komitetu.

Kolejny poważny problem konserwatorski wynika z samoczynnego, niekontrolowanego przekształcenia środowiska naturalnego na wzgórzu bł. Bronisławy. Lessowe wzgórze od wczesnego średniowiecza zagospodarowane przez pola orne i pastwiska było bezleśne. Po zarzuceniu upraw, koszenia łąk i wypasu, a także skutkiem dewastacji i rozbiórki zachodnich części fortu po 1945 r., nastąpił naturalny proces sukcesji krzewów i drzew na ruiny oraz zarastanie przedpola fortu. Wzgórze od ponad pół wieku zarasta samosiewnym lasem, co powoduje radykalną a niekorzystną zmianę krajobrazu. Rosnące $\mathrm{z}$ roku na rok drzewa przesłoniły już całkowicie fort i coraz bardziej przesłaniają Kopiec, którego np. od zachodu (znad wałów Rudawy, z Woli Justowskiej) już zupełnie nie widać. Mamy tu do czynienia z klasycznym konfliktem kultury z naturą, z krajobrazem porzuconym i zaniedbanym ${ }^{22}$. W celu odzyskania walorów krajobrazowych wzgórza bł. Bronisławy z Kopcem Kościuszki i fortem, należałoby przyjąć zasadę ochrony czynnej, czyli utemperować korony drzew rosnących najbliżej zabytkowego kompleksu (Kopiec i fort) oraz prześwietlić ten samosiewny gąszcz leśny, czyniąc zeń krajobraz parkowy. Komitet usilnie stara się o to, aby Kopiec Kościuszki, jako druga obok Wawelu, pełna znaczeń subdominanta krajobrazu kulturowego Krakowa - nie znikał, ale był widoczny. W nich - w Wawelu i Kopcu Kościuszki - nasz naród - jak to powiedział Jan Paweł II - „odczytuje - nie tylko swoją przeszłość - ale po prostu swoją tożsamość”.

\section{Zarządzanie}

Historycznym i prawnym opiekunem i zarządcą Kopca Kościuszki jest organicznie z nim związany od początku Komitet, który też od 25 lat jest administratorem części fortu. Komitet odradzający się w każdym pokoleniu przez kooptację, to nieliczne grono osób troszczących się o ten pomnik na co dzień. W ciągu już prawie 200 lat Komitet pod zarządem 11-tu kolejnych prezesów pełni swą posługę honorowo. Ustanowiony przez Senat Rządzący Rzeczypospolitej Krakowskiej w 1820 r. funkcjonował jako organ władzy Wolnego Miasta Krakowa. Po 1846 podlegał władzom Galicji we Lwowie. W 1924 r. rząd odrodzonej Rzeczypospolitej potwierdził jego legalność. Po 1945 r. Komitet nie mogąc działać na dotychczasowych zasadach schronił się pod skrzydła istniejącego od 1896 r. Towarzystwa Miłośników Historii i Zabytków Krakowa, gdzie zachowując autonomię, spełniał swą funkcję opiekuna i zarządcy Kopca, a jego prezes używał nadal starej pieczęci Komitetu ${ }^{23}$. W roku 2011 Komitet zredagował Statut i zarejestrował się w KRS zyskując osobowość prawną jako stowarzyszenie o nazwie „Komitet Kopca Kościuszki w Krakowie ustanowiony w 1820 r." Taka też jest treść jego starej i zachowującej swą legalność pieczęci. Komitet nigdy nie był ciałem licznym za to zawsze prominentnym. Obecnie Komitet liczy 17 członków zwyczajnych i 6 członków honorowych, pośród których

22 Rokosz M., Krajobraz z Kopcem Kościuszki. Szkic geograficzno-historyczny. The Kościuszko Mound and its surrouding landscape [w:] „Aura. Ochrona Środowiska” 7/2015, s. 19-21.

23 Rokosz M., Wywód historyczno-prawny Kopca Kościuszki w Krakowie i dzieje ustrojowe jego Komitetu w latach 1820 - 2000.[w:] 180 lat Kopca Kościuszki..., j. w., s. 105 - 122. 
są profesorowie historii UJ, profesorowie PK, AGH, konserwatorzy, prawnik, muzealnicy, dyrektor Miejskiego Zarządu Zieleni, przedstawiciel Kapituly katedralnej wawelskiej, w tym trzej członkowie IKOMOS. Pośród członków honorowych widnieją nazwiska kardynała Franciszka Macharskiego, rektora UJ Franciszka Ziejki, dyrektora MCK prof. Jacka Purchli, sekretarza generalnego PAU Jerzego Wyrozumskiego, infułata Jerzego Bryły i prof. Antonego Bajdka prezesa-fundatora The American Association of the Friends of Kosciuszko at West Point. Komitet działa w trybie posiedzeń w systemie protokołu czynności i ma do dyspozycji Biuro Komitetu, na czele którego stoi dyrektor Biura, które zatrudnia 9 osób zajmujących 7 33/4 etatu. Dyrektor w imieniu prezesa i przy jego udziale prowadzi remonty nadzorowane przez Konserwatora miejskiego. Komitet zatrudnia firmę ogrodniczą do pielęgnacji trawnika na skarpach Kopca. Wszyscy podlegają prezesowi.

\section{Promocja}

Stanowiący niezbywalny i pierwszorzędny, obok Wawelu, składnik krajobrazu kulturowego, panoramy i perspektyw Krakowa - Kopiec Kościuszki ma ugruntowane miejsce w tej wewnętrznej „serdecznej” geografii Polski. Od pokoleń jest miejscem umiłowanym i odwiedzanym przez Polaków. Ze względu na Kościuszkę, bohatera międzynarodowej sławy, rośnie frekwencja odwiedzających go cudzoziemców z różnych kontynentów, co potwierdza miejsce Kopca w geografii globu. Sprzyja temu rozwój turystyki masowej w skali globalnej, ale też niewątpliwie kontakty Komitetu Kopca Kościuszki np. z West Point w Stanach Zjednoczonych, z Paryżem, Solurą, Rapperswilem czy Kosciuszko Heritage w Melbourne. Narastająca na Kopcu frekwencja turystów w zasadzie nie grozi negatywnymi skutkami antropopresji, ponieważ na tym zabytkowym obiekcie ze względu na znaczną stromość skarp, można się poruszać tylko wybrukowanymi ścieżkami. Promocji Kopca Kościuszki służą też wydawane przez Komitet publikacje polskie i obcojęzyczne (angielski, francuski, rosyjski i niemiecki) a także publikacje zagraniczne oraz referaty prezesa Komitetu, odpowiadające na pytanie czym jest i jak wiele znaczy ten Kopiec, głoszone w Polsce i w/w środowiskach za granicą. Elementem promocji są też artykuły w prasie codziennej, wywiady radiowe i telewizyjne. Za element promocji można uznać darmowe wstępy na Kopiec dla grup zorganizowanych (w uzasadnionych wypadkach), czy darmowe wstępy dla uczestników jubileuszowego Zlotu Związku Harcerstwa Polskiego w 2011 r., i ulgowe wstępy na Kopiec w Światowe Dni Młodzieży w Krakowie 2016 roku. Elementem promocji są też dni wolnego wstępu na Kopiec. Obecnie są tą: 5 lutego, 24 marca, i 15 października. Za promocję uznać można informacje o Kościuszce i Kopcu, z którymi Komitet docierał do uczestników Kongresu esperantystów w Lizbonie w lipcu 2018 roku, itp.

Codzienną ozdobą Kopca Kościuszki są powiewające na szczycie polskie flagi, w dniu zaś 4 lipca, w święto narodowe Amerykanów, obok flagi polskiej, powiewa flaga amerykańska, a 14 lipca w święto narodowe Francuzów, flaga francuska. 3 maja, 11 listopada a także 15 sierpnia od szczytu Kopca do podstawy „spływa” szeroka, dobrze widoczna z miasta, flaga biało-czerwona. Jest to podkreślenie charakteru Kopca Kościuszki jako narodowego pomnika. 
O swoistym magnetyzmie Kopca Kościuszki i nieustannym, a nawet rosnącym zainteresowaniu świadczy frekwencja. W r. 2013 Kopiec odwiedziły 106182 osoby, w r. $2014-119273$ osoby, w r. 2015 - 127703 osoby, w roku 2016 - 133732 osoby, w r. 2017 - 147706 osób, a w r. 2018 - 169674 osoby. Obserwujemy wiec wyraźną tendencję wzrostową. W dni świąt narodowych, wolnego wstępu i inne pogodne dni ustawiają się długie, nieustające kolejki chętnych do wejścia na Kopiec Kościuszki.

Znaczącym wydarzeniem promującym Kopiec Kościuszki był Zlot młodzieży polskiej z okazji 200-lecia zgonu Kościuszki, inaugurowany pod Kopcem 12 października 2017 r., jak też zorganizowana w dniach $13-14$ października 2017 r. międzynarodowa Konferencja Kościuszkowska z udziałem referentów z 9 krajów z czterech kontynentów ${ }^{24}$.

W związku z obchodami 100-lecia odzyskania przez Polskę niepodległości Kopiec Kościuszki jest miejscem licznych imprez rocznicowych często o skali ogólnopolskiej, np. rajdów młodzieży z Kopca Kościuszki na Kopiec Piłsudskiego. Komitet i jego prezes nie ustają w staraniach, by Kopiec Kościuszki stał się miejscem otwartej na współczesny świat edukacji patriotycznej w kościuszkowskim duchu.

Przyszła stała wystawa muzealna pod Kopcem: „Kościuszko bohater wciąż potrzebny” z pewnością przyczyni się do wzrostu jego ideowego oddziaływania.

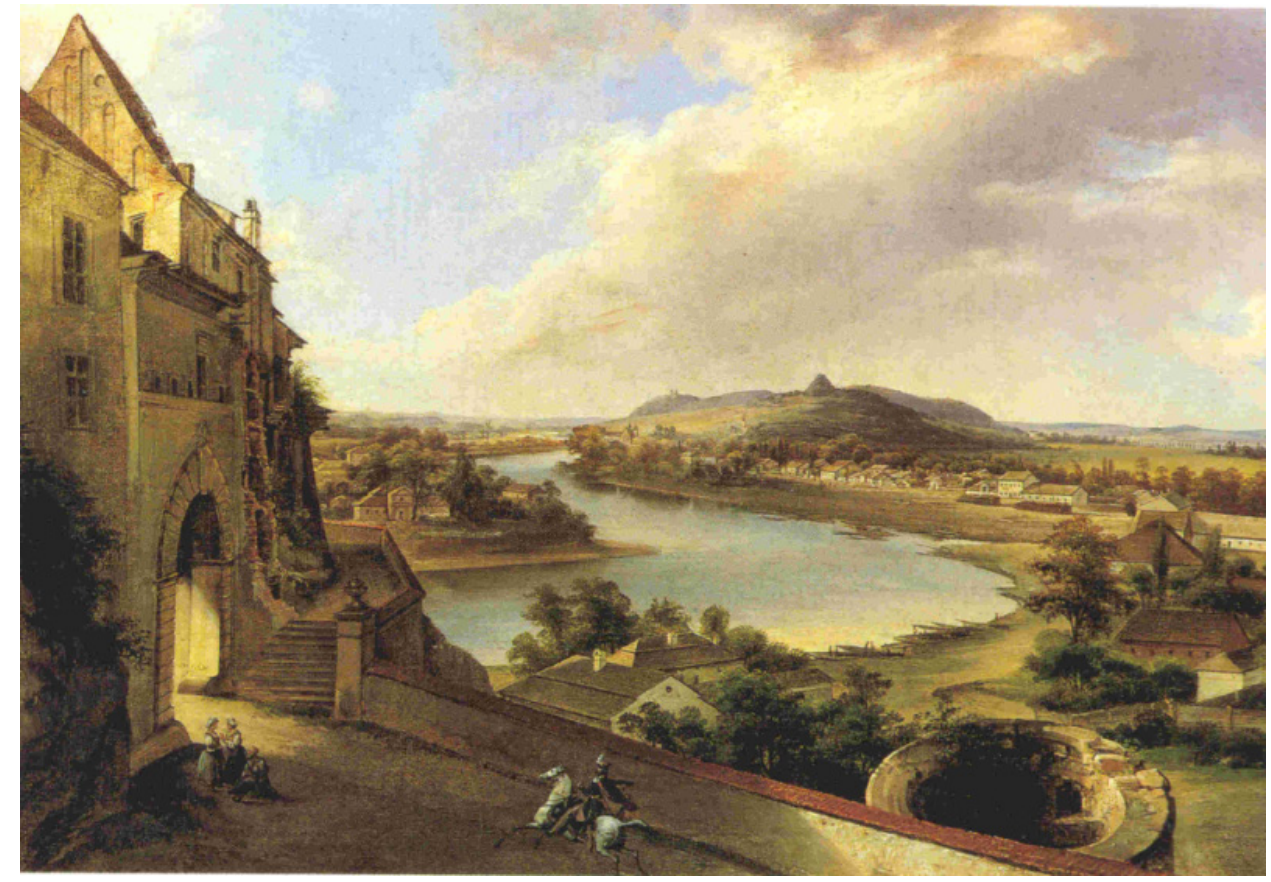

Fot. 1 Franciszek Macke (Matzke), kopia obrazu Jana Nepomucena Głowackiego, Widok $z$ Wawelu na zakola Wisty i Mogiłę Kościuszki (1846); swoista kwintesencja polskiego krajobrazu.(MN Kraków)

24 Zob. Rokosz M., Obchody Roku Kościuszki w Krakowie. Czynności Komitetu Kopca Kościuszki w Krakowie od 23 marca 2017 do 23 kwietnia 2018 roku [w:] „Rocznik krakowski” t. LXXXIV, Kraków 2018, s. 157 - 170. 


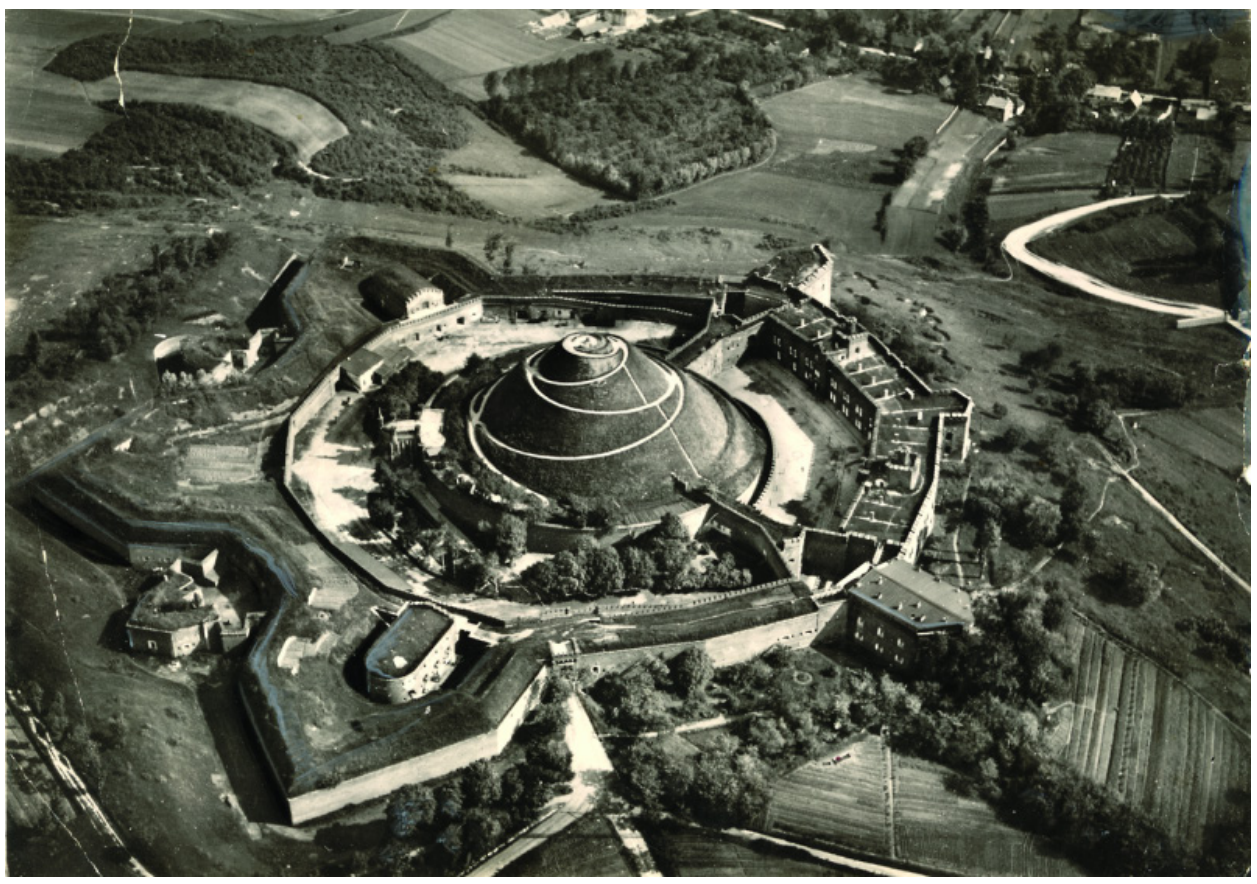

Fot. 2 Mogiła Kościuszki i Fort „Kościuszko” z lotu ptaka od strony zachodniej. Fot. Agencja Fotograficzna „Światowid” 1935. Muz. Hist. M. Krakowa

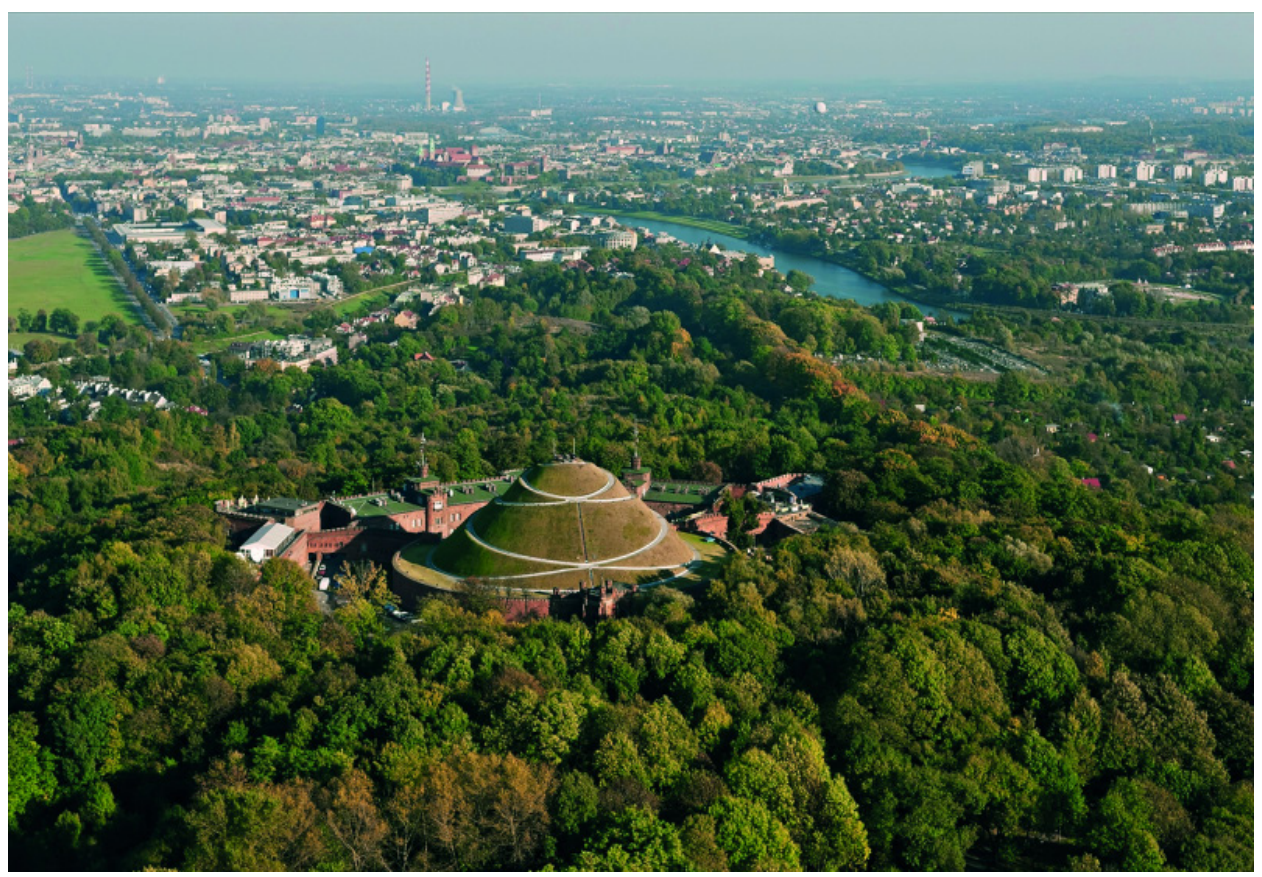

Fot. 3 Kopiec Kościuszki od ponad pół wieku zarasta samosiewny las. Fot. Piotr Krzan, zbiory Komitetu Kopca Kościuszki 


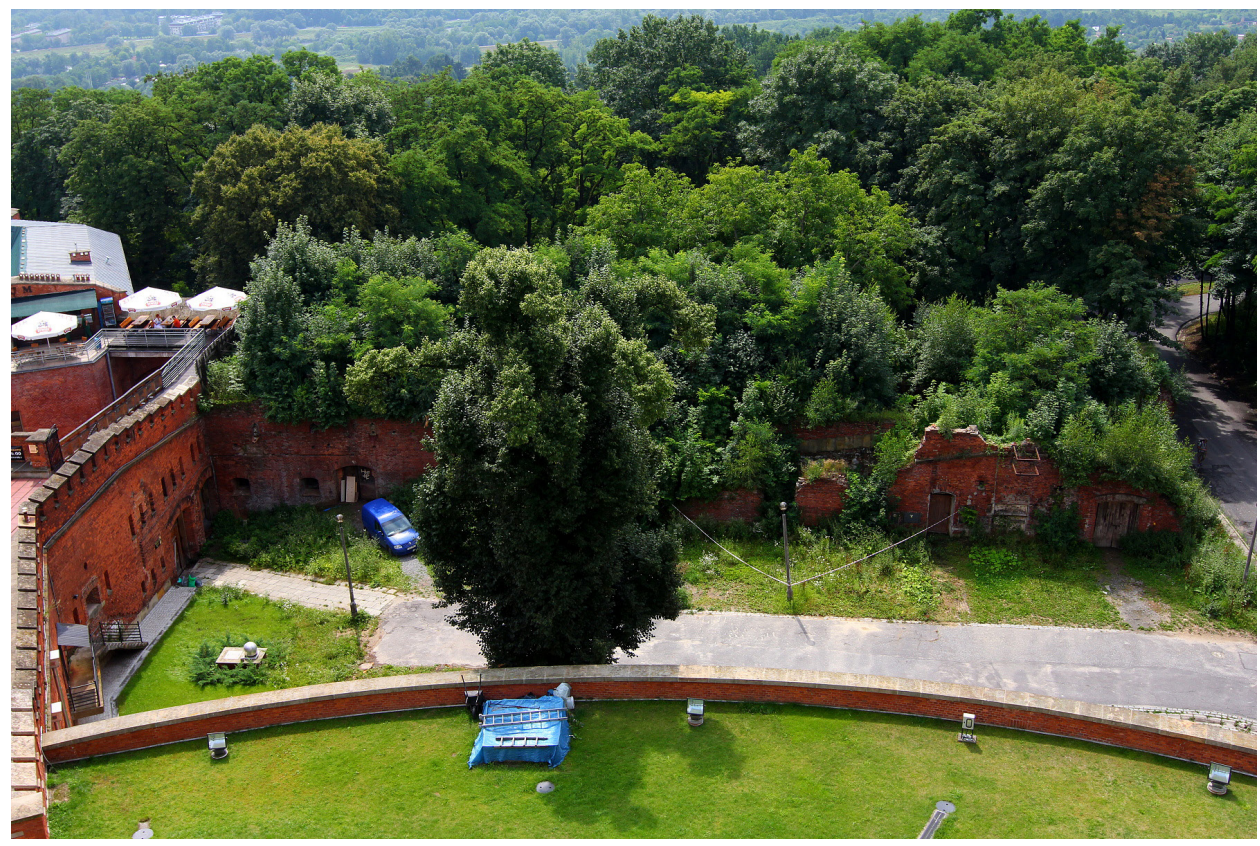

Fot. 4 Kurtyna przed remontem konserwatorsko-adaptacyjnym. Zbiory Komitetu Kopca Kościuszki

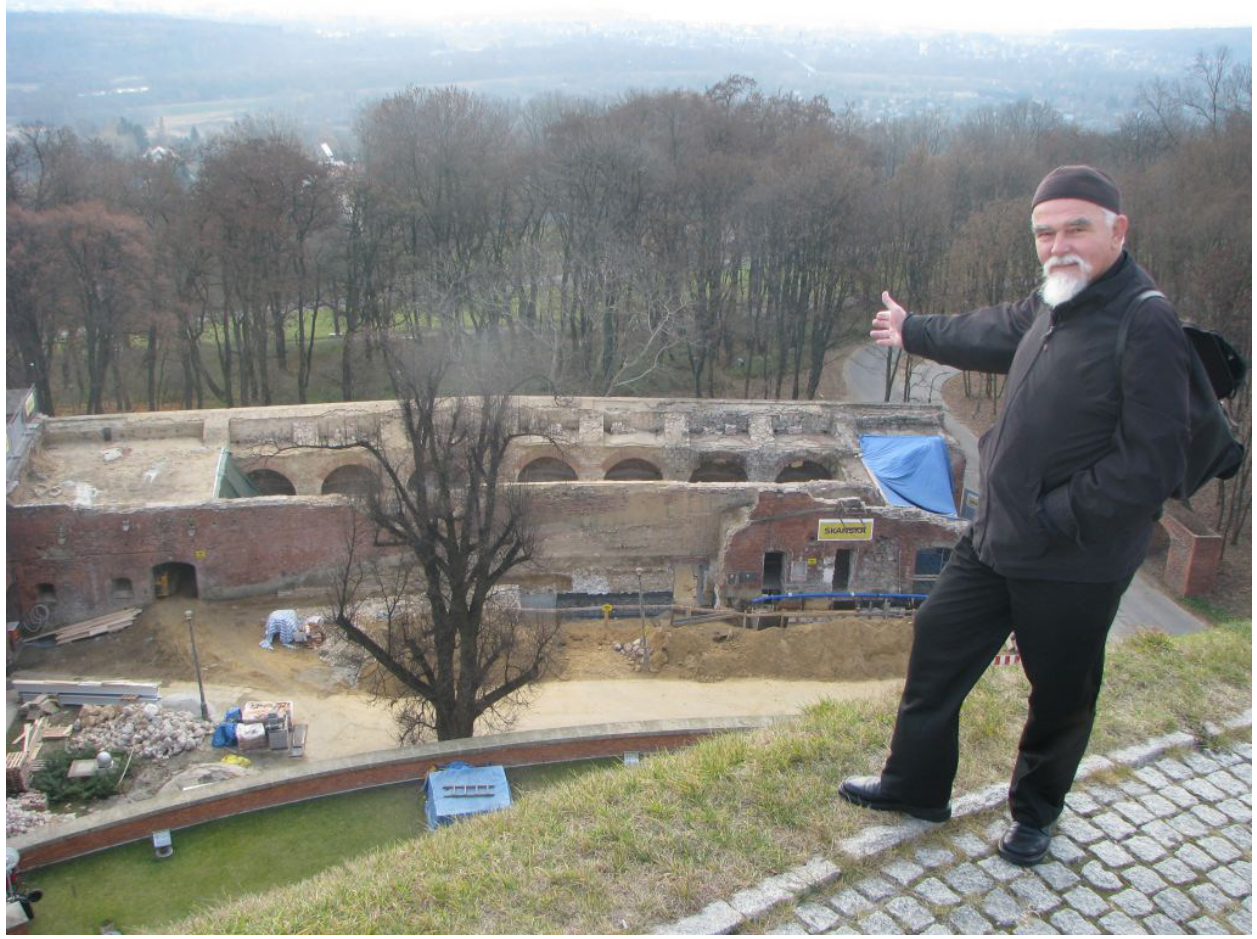

Fot. 5 Kurtyna po wykarczowaniu drzew i wybraniu ziemi. Zbiory Komitetu Kopca Kościuszki 


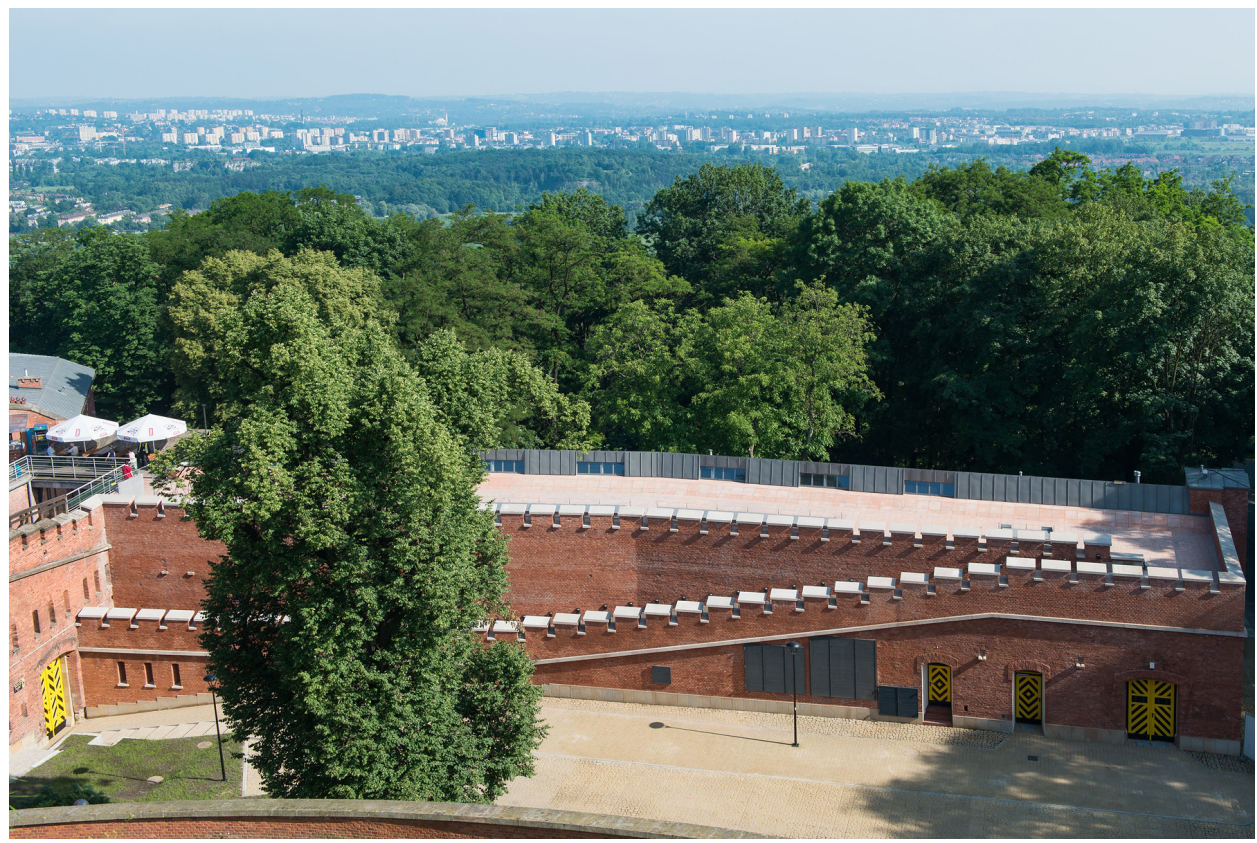

Fot. 6 Kurtyna po remoncie. Zbiory Komitetu Kopca Kościuszki

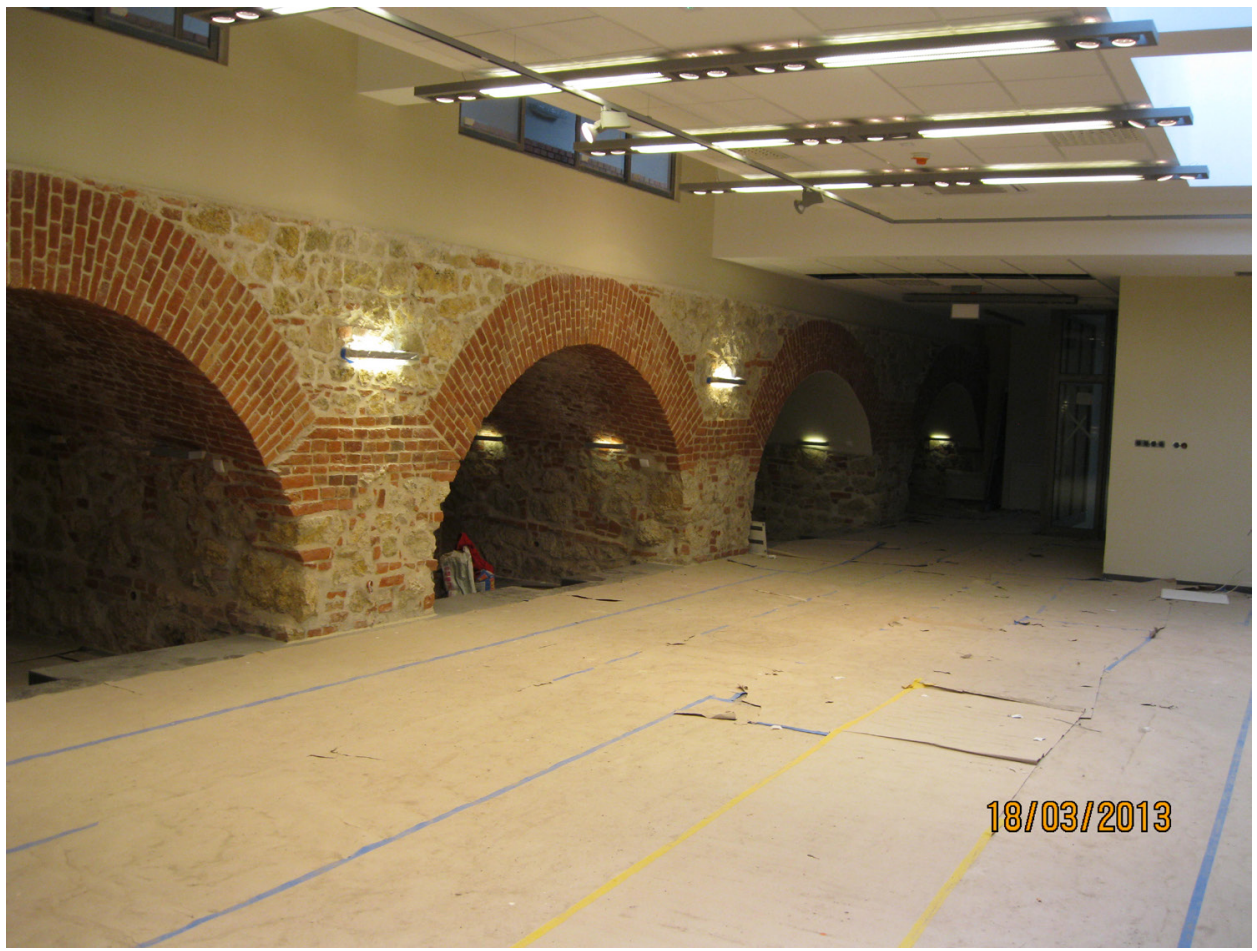

Fot. 7 Fragment wnętrza Kurtyny w trakcie remontu. Zbiory Komitetu Kopca Kościuszki 


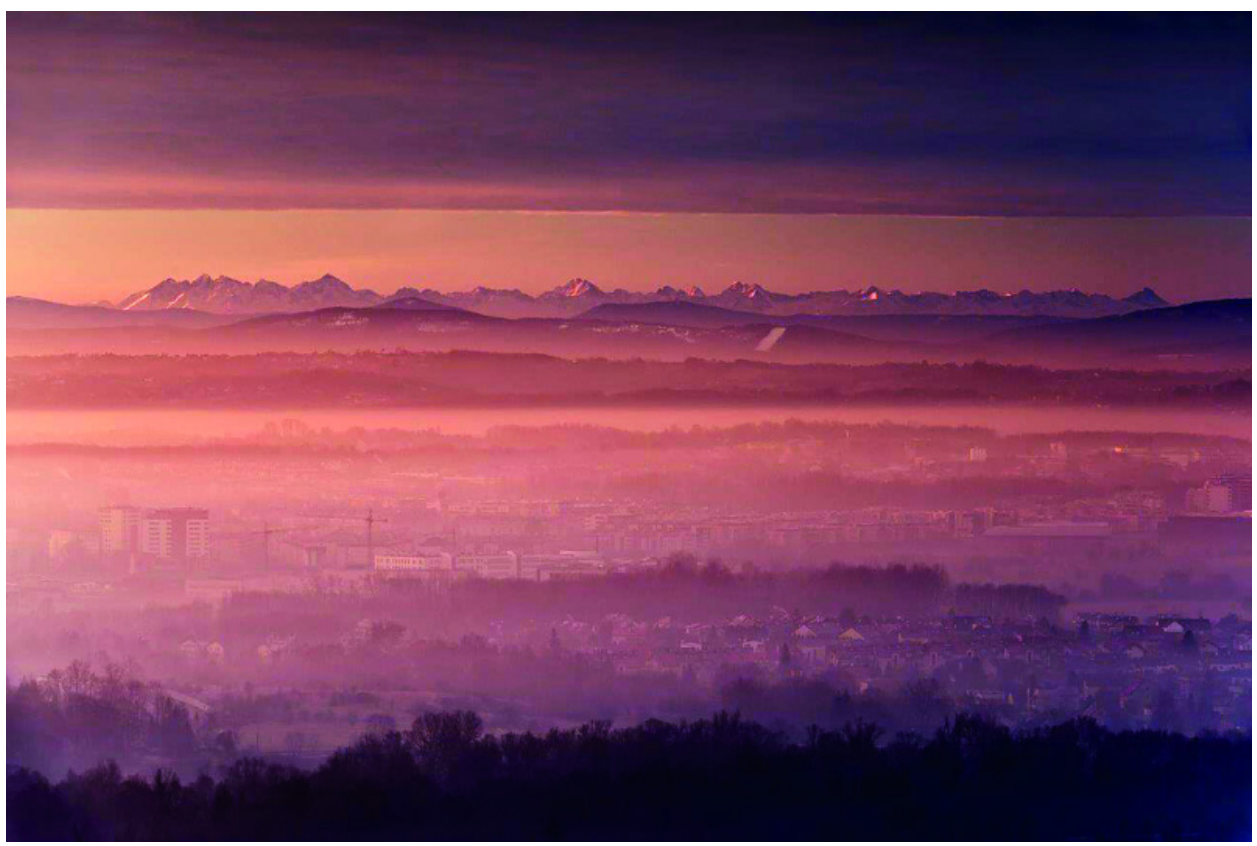

Fot. 8 Widok z Kopca Kościuszki o wschodzie słońca w stronę Tatr. Fot. Piotr Krzan. Zbiory Komitetu Kopca Kościuszki

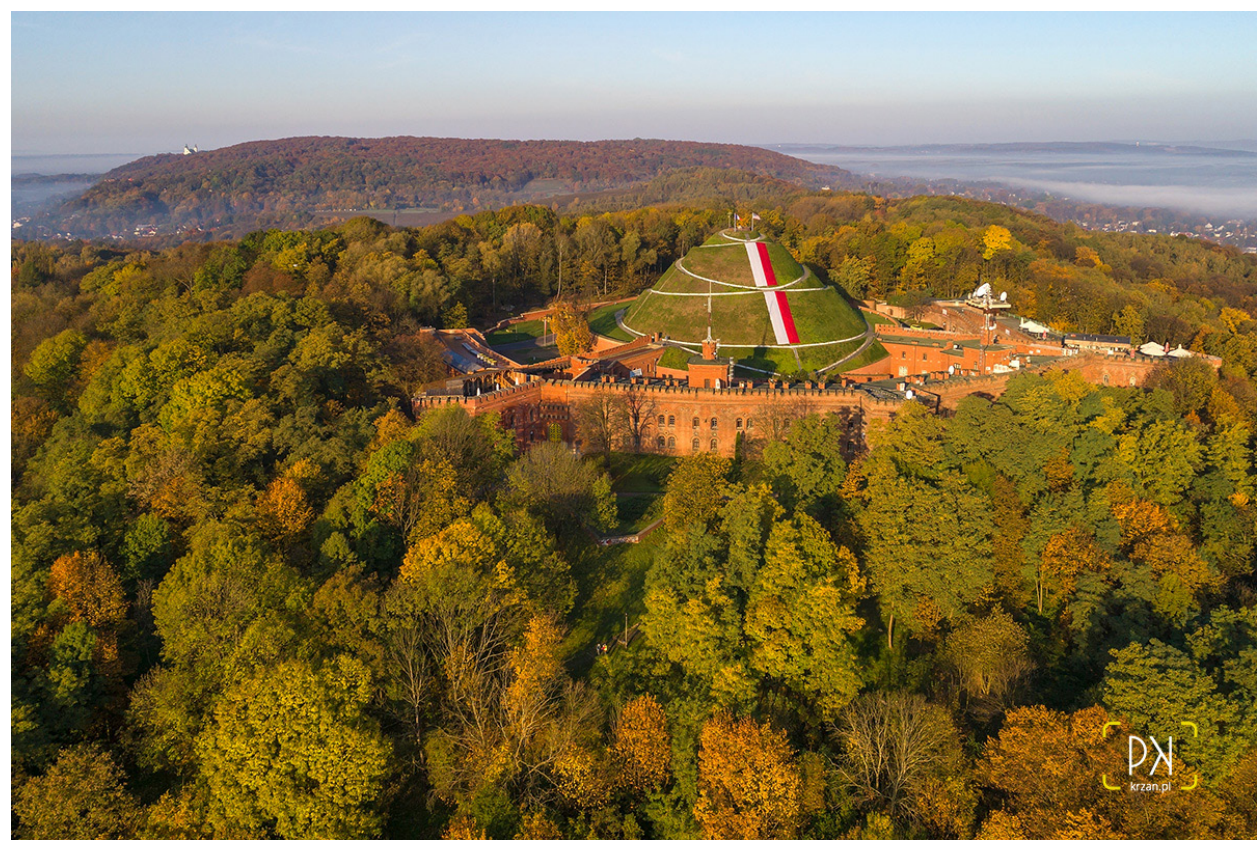

Fot. 9 Tak wygląda Kopiec Kościuszki w święta narodowe i dni uroczyste. Fot. Piotr Krzan, zbiory Komitetu Kopca Kościuszki 


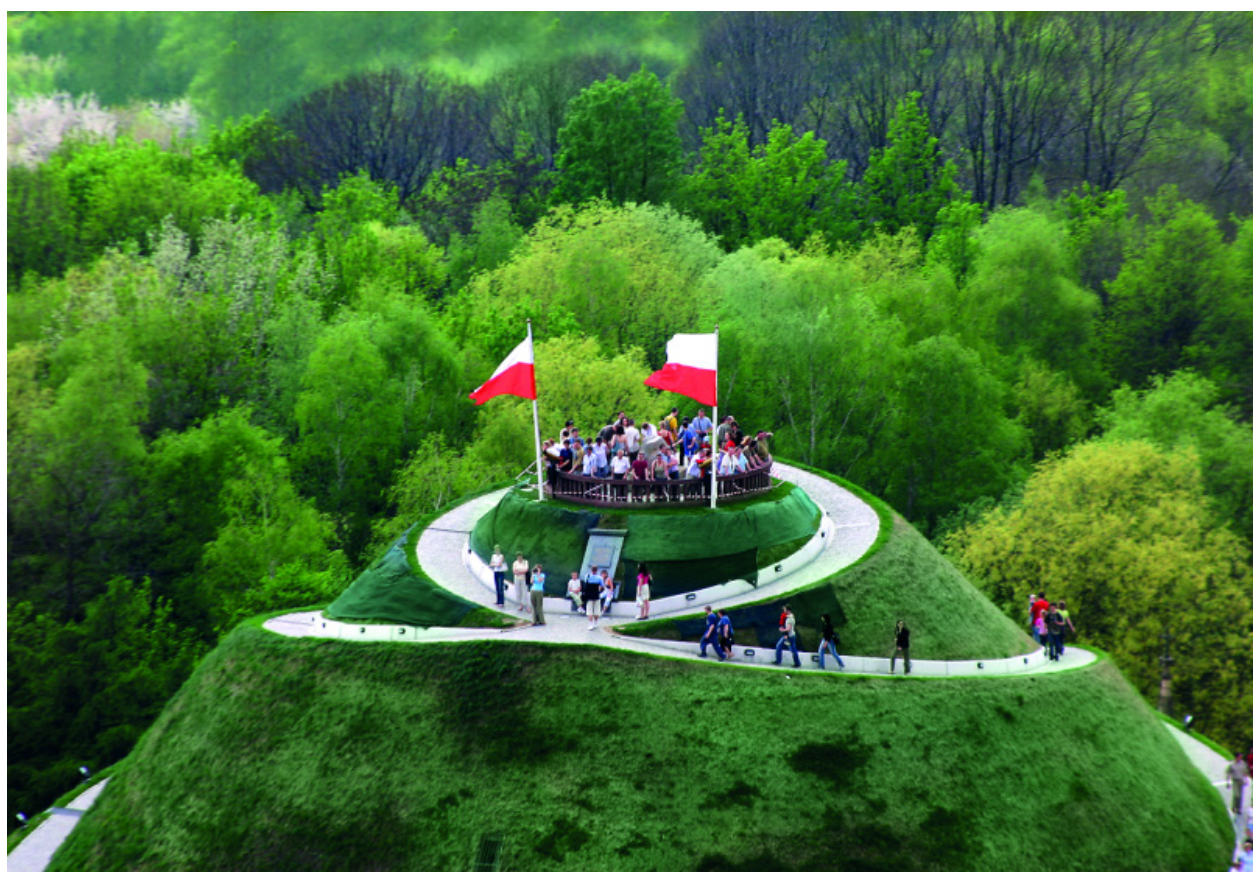

Fot. 10 Szczyt Kopca Kościuszki w dzień powszedni. Fot. Piotr Krzan, zbiory Komitetu Kopca Kościuszki 


\section{Bibliografia}

Bogdanowski J., 1966, Fortyfikacje austriackie na ziemiach polskich w latach 1850 - 1914 „Studia do Historii Wojskowości” t. XII, cz.1, Warszawa;

Danowska E., 2017, Jak powstawał Kopiec Kościuszki w Krakowie - jego dzieje w czasach Rzeczypospolitej Krakowskiej [w:] „Krakowski Rocznik Archiwalny” XXIII, Kraków, s. 45 - 63;

Fort 2 „Kościuszko” 1994, „Atlas Twierdzy Kraków” Seria I, Tom 3, Towarzystwo Miłośników Historii i Zabytków Krakowa - Komitet Kopca Kościuszki, Kraków;

Gordziałkowski J., 1994, Dzieje Komitetu Kopca Kościuszki (1820 - 1994) [w:] Kościuszce w hołdzie, red. M. Rokosz, Kraków, s. 85 - 184;

Gordziałkowski J., 2001, Kopiec Kościuszki - miejsce pielgrzymek Polaków [w:] 180 lat Kopca Kościuszki Materiały z sesji naukowej odbytej 15 kwietnia 2000 roku. Towarzystwo Miłośników Historii i Zabytków Krakowa. Kraków, s.15 - 103;

Janczykowski J., 2001, Historia i rewaloryzacja Fortu 2 „Kościuszko” [w:] 180 lat Kopca Kościuszki..., j. w. s. 147 - 166;

Niezabitowski M., 2001, Zbiory Komitetu Kopca Kościuszki i Muzeum Kościuszkowskie w Krakowie [w:] 180 lat Kopca Kościuszki. Materiały z sesji naukowej odbytej 15 kwietnia 2000 roku. Towarzystwo Miłośników Historii i Zabytków Krakowa, Kraków, s.123 - 146;

Pamiętnik budowy Pomnika Tadeusza Kościuszki przez Komitet zarzadzający tąż budowa wydany, Kraków 1825 [1826]; Dodatek do Pamiętnika budowy Pomnika Tadeusza Kościuszki wydanego w 1825 roku, obejmujacy sprawozdanie Komitetu Pomnikiem tym zarzadzającego za czas do 1 lipca 1851 r. Kraków 1852; Dodatek drugi do Pamiętnika Pomnika Kościuszki obejmujący czas od 1 lipca 1851 do końca 1876 roku. Kraków 1878;

Rokosz M., 2001, Wywód historyczno-prawny Kopca Kościuszki w Krakowie i dzieje ustrojowe jego Komitetu w latach 1820 - 2000 [w:] 180 lat Kopca Kościuszki. Materiały z sesji naukowej odbytej dnia 15 kwietnia 2000 roku. Towarzystwo Miłośników Historii i Zabytków Krakowa. Kraków;

Rokosz M. , 2001, Katastrofa Kopca Kościuszki w 1997 roku i pierwsze próby ratowania zabytku [w:] 180 lat Kopca Kościuszki..., j. w., s. 167 - 175;

Rokosz M., 2015, Krajobraz z Kopcem Kościuszki. Szkic geograficzno-historyczny. The Kościuszko Mound and its surrouding landscape [w:] „Aura. Ochrona Srodowiska” 7/2015, s. 19 - 21;

Rokosz M., 2016, Najkrótsza historia budowy i napraw Kopca Kościuszki „z ojczystej ziemi i z głazu krajowego" [w:] Kopiec Kościuszki i jego podłoże geologiczne. Atlas - Przewodnik. red. A. Wójcik, wyd. Urząd Miasta Krakowa, Wydział Kształtowania Środowiska, Kraków s. 6 - 22; Rokosz M., 2017, Kopiec Kościuszki w Krakowie: czym jest i co znaczy / Krakow's Kościuszko Mound what is and its significance? [w:] Tadeusz Kościuszko - historia, wspótczesność, przyszłość. Relacje i zależności. Red. nauk. M. J. Żychowska. Politechnika Krakowska im. Tadeusza Kościuszki. Kraków, s. 119 - 125;

Rokosz M., 2017, Le tertre do Kościuszko a Cracovie: Quest - ce que c’est et quelle est sa signification? [w:] „Annales Academie Polonaise des Sciences. Cntre Scientificque a’ Paris” vol 19, 2017, s. 158 - 176; 
Rokosz M., 2018, Obchody Roku Kościuszki w Krakowie. Czynności Komitetu Kopca Kościuszki w Krakowie od 23 marca 2017 do 23 kwietnia 2018 roku [w:] ,Rocznik Krakowski” t. LXXXIV, Kraków 2018, s. 157 - 170;

Rokosz M., 2017, Kopiec Tadeusza Kościuszki w Krakowie - znak wiecznotrwały [w:] Rozważny i romantyczny. W 200. Rocznice śmierci Tadeusza Kościuszki. Muzeum Historyczne Miasta Krakowa. Kraków, s.193 - 211;

Rożek M., 1981, Kopiec Kościuszki w Krakowie. Wydawnictwo Literackie Kraków;

Szydłowski T., 1926, Opieka nad zabytkami miasta Krakowa. Z działalności Urzędu konserwatorskiego [w:] „,Rocznik Krakowski” 20, 1926, s. 192;

Szydłowski T., 1929, Kronika konserwatorska z lat 1925 do 1928 [w:] „Rocznik Krakowski” 22, 1929, s. 143;

Tylutki J., 2001, Założenia projektowe odbudowy Kopca Kościuszki w Krakowie [w:] 180 lat Kopca Kościuszki ... s. 177 - 181;

Sprawozdania z czynności Komitetu Kopca Kościuszki publikowane na łamach „Rocznika Krakowskiego" od t. LX, 1994 r.; w t. LXI -LXIII z lat 1995 - 1997 skrócone sprawozdania w ramach Sprawozdań z działalności Towarzystwa Miłośników Historii i Zabytków Krakowa; od t. LXIV, 1998 Sprawozdania z czynności Komitetu Kopca Kościuszki. 
